University of Nebraska - Lincoln

DigitalCommons@University of Nebraska - Lincoln

Publications from USDA-ARS / UNL Faculty

U.S. Department of Agriculture: Agricultural

Research Service, Lincoln, Nebraska

April 2001

\title{
Erythropoietin mRNA expression in pig embryos
}

H. G. Klemcke

USDA-ARS, US Meat Animal Research Center

J. L. Vallet

USDA-ARS, US Meat Animal Research Center

R. K. Christenson

USDA-ARS, US Meat Animal Research Center

P. L. Pearson

USDA-ARS, US Meat Animal Research Center

Follow this and additional works at: https://digitalcommons.unl.edu/usdaarsfacpub

Part of the Agricultural Science Commons

Klemcke, H. G.; Vallet, J. L.; Christenson, R. K.; and Pearson, P. L., "Erythropoietin mRNA expression in pig embryos" (2001). Publications from USDA-ARS / UNL Faculty. 186.

https://digitalcommons.unl.edu/usdaarsfacpub/186

This Article is brought to you for free and open access by the U.S. Department of Agriculture: Agricultural Research Service, Lincoln, Nebraska at DigitalCommons@University of Nebraska - Lincoln. It has been accepted for inclusion in Publications from USDA-ARS / UNL Faculty by an authorized administrator of DigitalCommons@University of Nebraska - Lincoln. 


\title{
Erythropoietin mRNA expression in pig embryos ${ }^{\text {th }}$
}

\author{
H.G. Klemcke*, J.L. Vallet, R.K. Christenson, P.L. Pearson \\ USDA, Agricultural Research Service, US Meat Animal Research Center, P.O. Box 166, \\ Clay Center, Nebraska, NE 68933-0166, USA
}

Received 28 March 2000; received in revised form 15 November 2000; accepted 24 November 2000

\begin{abstract}
To address whether altered erythropoietin (EPO) synthesis might be involved in prenatal pig mortality, studies were conducted to measure porcine embryonic EPO mRNA expression during early gestation (days 24-40). Three pig models differing in embryonic survival from days 24-40 were investigated: intact white crossbred gilts (INT), white crossbred gilts that were unilaterally hysterectomized-ovariectomized before puberty and whose pregnant uterus constituted a crowded environment (UHO), and prolific, intact Meishan gilts (ME). A partial cDNA for porcine EPO, developed via reverse transcription and polymerase chain reaction procedures was used to generate $\mathrm{a}{ }^{32} \mathrm{P}$-labeled probe for use in Northern analyses. In an initial study, embryonic liver EPO mRNA was greatest on day 24 , decreased by day $30(P<0.01)$, and was barely detectable by day 40 . EPO mRNA expression was not influenced by pig model. Placental EPO mRNA expression was detectable in only 4 of 53 placentae examined. In a second study at day 35 of gestation, embryonic liver EPO mRNA expression was measured in the same three pig models and in two embryos of divergent weights from each gilt. Meishan embryos had lower $(P<0.01)$ plasma immunoassayable EPO concentrations $(P=0.04)$ and higher survival rates $(87 \pm 2.7 \%)$ at day 35 than did white crossbred embryos $(75 \pm 5 \%)$. Liver EPO mRNA expression did not differ among animal models, nor did plasma EPO or tissue EPO mRNA expression differ between large and small embryos. There was no apparent relationship between embryonic development, measured as embryonic and placental size, and plasma EPO concentrations or liver EPO mRNA expression. These results indicate that at the gestational ages examined, the embryonic liver is one source of plasma erythropoietin and suggest that at the ages sampled, EPO is not a limiting factor in embryonic development. Published by Elsevier Science B.V.
\end{abstract}

Keywords: Erythropoietin; mRNA; Embryos; Pigs; Development

\footnotetext{
Mention of trade names or commercial products in this article is solely for the purpose of providing specific information and does not imply recommendation or endorsement by the US Department of Agriculture.

* Corresponding author. Present address: US Army Institute of Surgical Research, 3400 Rawley E. Chambers Avenue, Fort Sam Houston, TX 78234, USA. Tel.: +1-210-916-3732; fax: +1-210-916-2942.

E-mail address: harold.klemcke@cen.amedd.army.mil (H.G. Klemcke).
}

0378-4320/01/\$ - see front matter Published by Elsevier Science B.V. PII: S 0378-4320(01)00084-7 


\section{Introduction}

Prenatal mortality in swine can be as great as 50\%. On the average, 20-30\% of fetuses die before day 30 and another 10-20\% from day 40 to term (Pope, 1994). When the uterine environment is artificially crowded, additional mortality occurs between days 25 and 40 of gestation (Webel and Dziuk, 1974; Knight et al., 1977). Chinese Meishan pigs have increased litter sizes compared with contemporary white crossbreds due to increased ovulation rates and enhanced prenatal survival throughout gestation (Christenson et al., 1993). Enhanced ME embryonic survival has been measured at day 30 of gestation (Bazer et al., 1988).

Erythropoiesis in swine fetuses undergoes dramatic maturational changes during days 25-40 of gestation (Pearson et al., 1998). As successful erythropoiesis is a prerequisite for fetal survival, it has been suggested that abnormal erythropoiesis might be causally related to embryo mortality during this time (Pearson et al., 1998).

Erythropoietin (EPO) is a glycosylated hormone and growth factor that is required for successful erythropoiesis (Fisher, 1997). The primary stimulus for EPO production in adults is tissue hypoxia (Jelkmann, 1992). It has been suggested that oxygen tension is sensed by a heme protein (Goldberg et al., 1988; Galson et al., 1994) or non-heme protein (Srinivas et al., 1998) that transduces the reduced oxygen signal into an increase in EPO mRNA that is due primarily, but not exclusively, to increased transcription (Galson et al., 1994; Bunn et al., 1998). Erythropoietin in most adult species is produced primarily by the peritubular fibroblasts in the kidney cortex and outer medulla (Maxwell et al., 1990). During fetal development, however, the site of EPO synthesis varies in a species-dependent manner. In rodent species, EPO is synthesized primarily by the fetal liver throughout most of gestation (Eckardt, 1995). In mice, a brief period of synthesis by the visceral yolk sac precedes that in the liver (Rich et al., 1994). In sheep the liver and kidney are major sources by day 41 of gestation (Wintour et al., 1996). In addition, human placental trophoblast cells appear to be a site of EPO production throughout most of gestation (Conrad et al., 1996).

Erythropoietin in the blood of porcine embryos has recently been measured (Pearson et al., 1998) as early as day 30 of gestation (term = 114 days); however, the source of this erythropoietin has not been determined. In the current studies, three different animal models with differences in prenatal survival at 24-40 days of gestation were used to address the following objectives: (1) determine if EPO mRNA is expressed in the porcine liver (the predicted primary site of EPO expression) at days 24, 30, and 40 of gestation and (2) determine if plasma EPO or liver EPO mRNA expression were related to embryonic development at an age (day 35) when embryos were anticipated to be experiencing increased mortality in a crowded uterine environment.

\section{Materials and methods}

\subsection{Animals and tissue collections}

White crossbred (WC) gilts either remained intact (INT) or were unilaterally hysterectomized-ovariectomized (UHO) at approximately 160 days of age as previously described (Christenson et al., 1987). Meishan (ME), INT, and UHO gilts were bred to boars of the 
same breed and randomly assigned to be slaughtered at days 24,30 , or 40 (initial study) or day 35 (second study) of pregnancy. A total of $58 \mathrm{WC}$ and $30 \mathrm{ME}$ gilts were used for both studies. WC gilts were bred at 262-320 days of age after at least one oestrous cycle of normal length. ME gilts were bred at 272-308 days of age after more than seven oestrous cycles. This ensured that an increased ovulation rate would occur in ME compared with WC gilts (Christenson et al., 1993). Day 0 was designated as the first day of behavioral oestrus. Pigs were maintained in groups of 10-20 in indoor swine facilities at the US Meat Animal Research Center. Gilts received water ad libidum and $1.8-2.3 \mathrm{~kg}$ daily of a corn and soybean-meal diet. For the initial study, reproductive tracts were removed at slaughter and fetal tissues subsequently obtained. Liver and placental samples were obtained from random fetuses, rapidly frozen in liquid nitrogen, and stored at $-80^{\circ} \mathrm{C}$ until used in assay procedures. Tissue removal began within $5 \mathrm{~min}$ of slaughter and continued until fetuses within a tract were sampled $(\sim 45 \mathrm{~min})$. In the second study, pregnant gilts were anesthetized initially with sodium Pentothal (1 g/gilt) administered I.V. and then maintained under 3-5\% halothane:95-97\% oxygen. A midventral laparotomy was performed and uterine horns were gently exteriorized and covered with a sterile towel that was kept constantly moist with warm $\left(37^{\circ} \mathrm{C}\right)$ sterile saline. A hysterotomy was then performed along the antimesometrial border and one embryo exposed. A blood sample was obtained from an umbilical artery, the embryo removed and weighed, and a small placental sample taken. These latter procedures were repeated until all embryos in both uterine horns had been exposed, sampled, and removed from the uterus. Embryos were dissected immediately and liver and kidney tissue removed (kidney tissue was not taken from Meishan embryos). All tissues were immediately frozen in liquid nitrogen. After all embryos were removed from the uterus, a complete ovariectomy-hysterectomy was performed. In this latter study, measures were conducted specifically in two embryos of greatly divergent weights within each gilt. It was our hypothesis that these two groups (large and small) would adequately represent those embryos that were developing normally (large embryos) and those that would be experiencing developmental problems (small embryos). Blood samples were placed on ice, centrifuged $1500 \times g_{\text {av }}$ for $20 \mathrm{~min}$, and plasma stored at $-20^{\circ} \mathrm{C}$. All procedures involving use and slaughter of animals were approved by our institutional Animal Care and Use Committee.

\subsection{RNA extraction and RT-PCR}

Total RNA was isolated from tissue samples using RNeasy Kits (QIAGEN, Chatsworth, CA). Porcine cDNA for EPO, $\beta$-actin, and glyceraldehyde-3-phosphate dehydrogenase (GAPDH) (the latter two mRNA to be used to correct for RNA loading differences among lanes) were then generated. To produce these cDNA reverse transcription (RT) was conducted with previously prepared total RNA from neonatal pig kidney (EPO), adult pig kidney ( $\beta$-actin), or uterine endometrium from day 30 of pregnancy (GAPDH) after treatment with DNase (Promega Corp., Madison, WI), and purification on a QIAGEN RNeasy column. The RT reactions for EPO and $\beta$-actin used $2 \mu \mathrm{g}$ RNA, $1 \mu \mathrm{l}(1.6 \mathrm{ng})$ random nonamer primers (Amersham, Arlington Heights, IL), $1 \mu \mathrm{l}$ (200 units) Moloney Murine Leukemia Virus (M-MLV) Reverse Transcriptase (Promega Corp.), $1 \mu l$ (40 units) RNasin ribonuclease inhibitor (Promega Corp.), $5 \mu \mathrm{l}$ (10 mM) dNTPs (Promega Corp.), $8 \mu 1 \mathrm{M}-\mathrm{MLV}$ 
$5 \times$ reaction buffer (Promega Corp.), and sufficient diethyl pyrocarbonate-treated, autoclaved water to give a final volume of $40 \mu$. The reaction mixture was incubated at $37^{\circ} \mathrm{C}$ for $60 \mathrm{~min}$, then $95^{\circ} \mathrm{C}$ for $5 \mathrm{~min}$, and placed on ice. A cDNA for GAPDH was prepared as previously described (Vallet et al., 1999).

Appropriate forward (5' ACG CCT CAT CTG TGA CAG C $\left.3^{\prime}\right)$ and reverse (5' ACA GCT TTG TCC ACA TGC AG $3^{\prime}$ ) primers for porcine EPO were determined based on the known sequence of the $3^{\prime}$ end of porcine EPO mRNA (Wen et al., 1993). Forward (5' GAG ACC TTC AAC ACG CCG $3^{\prime}$ ) and reverse (5' GGA AGG TGG ACA GCG AGG $3^{\prime}$ ) primers for porcine $\beta$-actin, and forward ( $5^{\prime}$ CAC GAC CAT GGA GAA GGC $\left.3^{\prime}\right)$ and reverse ( $5^{\prime}$ GAA GCA GGG ATG ATG TTC TGG $3^{\prime}$ ) primers for porcine GAPDH (Vallet et al., 1999) were determined from a partial $\beta$-actin sequence (GeneBank Sequence Database, Accession no. U07786), and a complete GAPDH sequence (GeneBank Sequence Database, Accession no. AF017079). Primers were synthesized using an Oligo 1000 M DNA Synthesizer (Beckman Instruments, Inc., Fullerton, CA). Conditions for PCR included: (a) EPO; $1 \mu l$ each of forward and reverse primers $(20 \mu \mathrm{M}), 2 \mu \mathrm{l}$ dNTPs $(2.5 \mathrm{mM}$ dATP, dCTP, dGTP, dTTP),

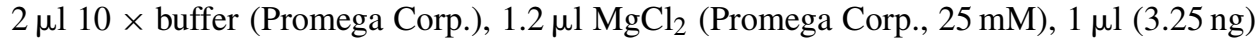
EPO cDNA template, $1 \mu \mathrm{l} \mathrm{Taq} \mathrm{DNA} \mathrm{polymerase} \mathrm{(Promega} \mathrm{Corp.),} \mathrm{and} 10.8 \mu l$ sterile water to provide a final volume of $20 \mu \mathrm{l}$. (b) $\beta$-Actin was identical except that $2 \mu \mathrm{l}(5 \mathrm{ng}$ ) of cDNA primer and $9.8 \mu \mathrm{l}$ sterile water were added. Thermocycler conditions for both were 94-95 ${ }^{\circ} \mathrm{C} \times 4 \mathrm{~min}, 94-95^{\circ} \mathrm{C} \times 1 \mathrm{~min}, 60^{\circ} \mathrm{C} \times 1 \mathrm{~min}, 72^{\circ} \mathrm{C} \times 2 \mathrm{~min}$, with the last three steps repeated 29 times. Conditions for GAPDH were similar except the final volume was reduced by 50\%: $1 \mu \mathrm{l}$ each of forward and reverse primers $(20 \mu \mathrm{M}), 1 \mu \mathrm{l}$ cDNA template $(1 \mathrm{ng})$, $1 \mu \mathrm{l} 10 \times$ buffer that contained $15 \mu \mathrm{M} \mathrm{MgCl}_{2}, 1 \mu \mathrm{dNTPs}, 0.5 \mu \mathrm{l}$ Taq polymerase, and $4.5 \mu \mathrm{l}$ sterile water. Thermocycler conditions for GAPDH were $95^{\circ} \mathrm{C} \times 1 \mathrm{~min}, 95^{\circ} \mathrm{C} \times 15 \mathrm{~s}$, $58^{\circ} \mathrm{C} \times 1 \mathrm{~min}, 68^{\circ} \mathrm{C} \times 1 \mathrm{~min}$, with the last three steps repeated 29 times (Vallet et al., 1999).

\subsection{Cloning}

The cDNA from PCR reactions were purified via use of a QIAquick PCR Purification Kit (QIAGEN), and then ligated into a pCRII plasmid vector and transformed into competent $E$. coli cells (TOP10F'; Invitrogen, Carlsbad, CA). Colonies were screened by PCR, DNA isolated from positive colonies, and then sequenced using primers specific for the pCRII vector (M13 reverse primer, 5' CAG GAA ACA GCT ATG AC 3'; M13 [-20] forward primer, 5' GAC CGG CAGCAA AAT G $3^{\prime}$ ) and reagents associated with the BigDye Terminator Cycle Sequencing Ready Reaction kit for sequencing on an ABI 377 automated DNA sequencer (Perkin-Elmer Corp., Applied Biosystems Division, Foster City, CA). Characteristics of cDNA produced for use in Northern analyses are presented in Table 1. The remainder of the purified plasmid was digested using Eco RI (Promega) followed by purification of the cDNA on a $1.2 \%$ agarose gel. The cDNA were cut from the gels and purified using the QIAquick gel extraction kit (QIAGEN).

\subsection{Northern analyses}

Total RNA from liver, kidney, and placental samples was isolated as noted above and $20 \mu \mathrm{g}$ (kidney) or $30 \mu \mathrm{g}$ (liver, placenta) portions loaded onto denaturing MOPS $1.25 \%$ 
Table 1

Characteristics of cDNA for porcine EPO, $\beta$-actin, and glyceraldehyde-3-phosphate dehydrogenase (GAPDH)

\begin{tabular}{lllll}
\hline CDNA & No. of bp & $\begin{array}{l}\text { Approximate size of } \\
\text { hybridized mRNA }\end{array}$ & $\begin{array}{l}\text { Percent homology with } \\
\text { known porcine sequence }(\%)\end{array}$ & Reference \\
\hline EPO & 294 & 1800 & 98.6 & Wen et al., 1993 \\
$\beta$-Actin & 685 & 2600 & 98.3 & GeneBank, no. U07786 \\
GAPDH & 324 & 1900 & 94.4 & GeneBank, no. AF017079 \\
\hline
\end{tabular}

agarose/formaldehyde gels. After electrophoresis, RNA was transferred by capillary blotting to nylon membranes (Hybond-N, Amersham, Arlington Heights, IL) and fixed to the membrane via UV crosslinking in a UV Stratalinker 2400 (Stratagene, LaJolla, CA). Labeled cDNA was prepared using the above-noted specific forward and reverse primers for each cDNA and PCR procedure that also included use of ${ }^{32} \mathrm{P}-\mathrm{dCTP}$ (Dupont New England Nuclear, Wilmington, DE). After separating labeled cDNA from unincorporated ${ }^{32} \mathrm{P}-\mathrm{dCTP}$, labeled cDNA $(\approx 1,000,000-1,5000,000 \mathrm{dpm} / \mathrm{ml}$ hybridization buffer $)$ was added to nylon membranes containing crosslinked RNA that were prehybridized for $1 \mathrm{~h}$ at $60^{\circ} \mathrm{C}$ in $10 \mathrm{ml} / \mathrm{membrane}$ of Rapid-hyb buffer (Amersham). The hybridization reaction continued for $2 \mathrm{~h}$ at $65^{\circ} \mathrm{C}$. Membranes were then washed twice with $2 \times 0.3 \mathrm{M}$ sodium chloride, $0.03 \mathrm{M}$ sodium citrate $\mathrm{pH} 7.0$ (SSC) containing $0.1 \%$ sodium lauryl sulfate (SDS) at $42^{\circ} \mathrm{C}$ for $30 \mathrm{~min}$. Additional washes with decreasing concentrations of SSC $(0.5-0.1 \times)$ and increasing temperatures $\left(60-65^{\circ} \mathrm{C}\right)$ were used to wash nonspecifically-bound radioactivity from the membranes. Membranes were then exposed to X-ray film (Eastman Kodak Co., Rochester, NY) at $-80^{\circ} \mathrm{C}$ for 2 weeks (EPO) or approximately $24 \mathrm{~h}$ ( $\beta$-actin, GAPDH). Densitometry measurements were conducted for EPO with a Ultrascan XL (Pharmacia LKB Biotechnology Inc., Piscataway, NJ) or with a ChemiImager (Alpha Innotech Corp., San Leandro, CA) for $\beta$-actin and GAPDH.

\subsection{Erythropoietin RIA}

A heterologous RIA procedure (Diagnostic Systems Laboratories, Webster, TX) previously validated for use with pig plasma (Pearson et al., 1998) was used to measure concentrations of EPO in embryonic pig plasma in Experiment II. All samples were analyzed in duplicate $50 \mu \mathrm{l}$ volumes in a single assay with an average CV of $5.8 \%$ and an assay sensitivity (lowest standard in the linear range of the standard curve) of $0.25 \mathrm{mU}$ per tube. Data are presented as $\mathrm{mU} / \mathrm{ml}$ relative to a human EPO standard.

\subsection{Statistics}

Each Northern blot consisted of each treatment $\times$ day of gestation combination and, therefore, constituted a block or replicate of the experiment. Densitometric measures for each experimental sample EPO mRNA were then analyzed by analysis of covariance using $\beta$-actin densitometric measures for the same sample as a covariate and using the PROC MIXED procedure of the Statistical Analysis System (SAS, 1997) that included blocks as a random term. Linear relationships among measures were analyzed using PROC MIXED 
and analysis of covariance procedures. All data were tested for homogeneity of variance with an F max test, and data transformed to a log function where necessary. Least square means \pm S.E.M. of original data are always presented. A probability level of $\leq 0.05$ was considered significant.

\section{Results}

\subsection{Experiment I}

Effects of treatments (animal models or gestational age) on fetal numbers, size, and survival have been previously reported for this study (Pearson et al., 1998). Briefly, fetal numbers on days 30 and 40 were greater in INT versus UHO $(P<0.01)$ and did not differ between INT and ME. Fetal weights were greater in WC (INT and UHO) versus ME at each day of gestation $(P<0.01)$. Percent survival was reduced $(P<0.05)$ in UHO compared with INT and ME on day 40.

Steady-state amounts of EPO mRNA in fetal liver appeared to be greatest on day 24 and decreased $(P<0.001)$ with gestational age (Figs. 1 and $2 \mathrm{a})$. There were, however, no treatment-associated differences at the ages measured $(P<0.63)$. Data for EPO presented in Fig. 2 a are adjusted via analysis of covariance to $\beta$-actin. If instead EPO is adjusted for

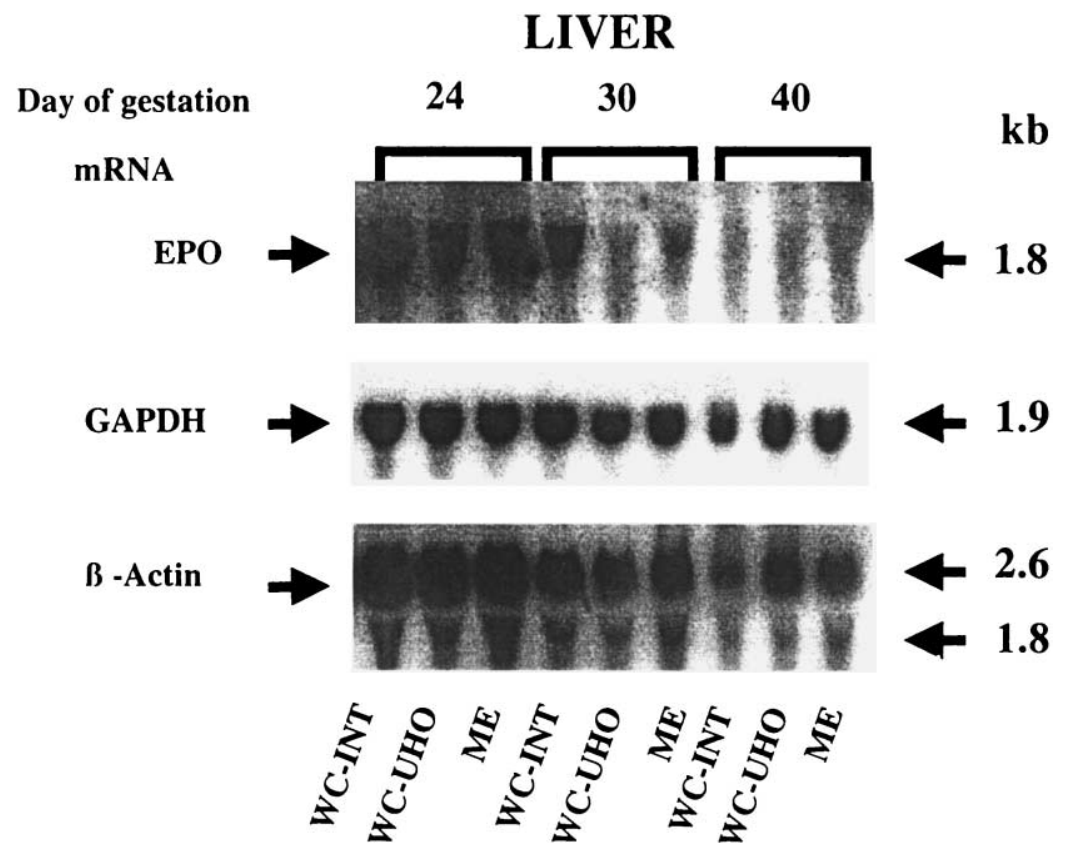

Fig. 1. Representative Northern analysis of EPO, glyceraldehyde-3-phosphate dehydrogenase (GAPDH), and $\beta$-actin mRNA from embryonic pig liver at various gestational ages. All lanes consisted of $30 \mu \mathrm{g}$ total RNA. WC-INT: intact white crossbred gilts; WC-UHO: unilaterally-hysterectomized-ovariectomized white crossbred gilts; ME: intact Meishan gilts. 

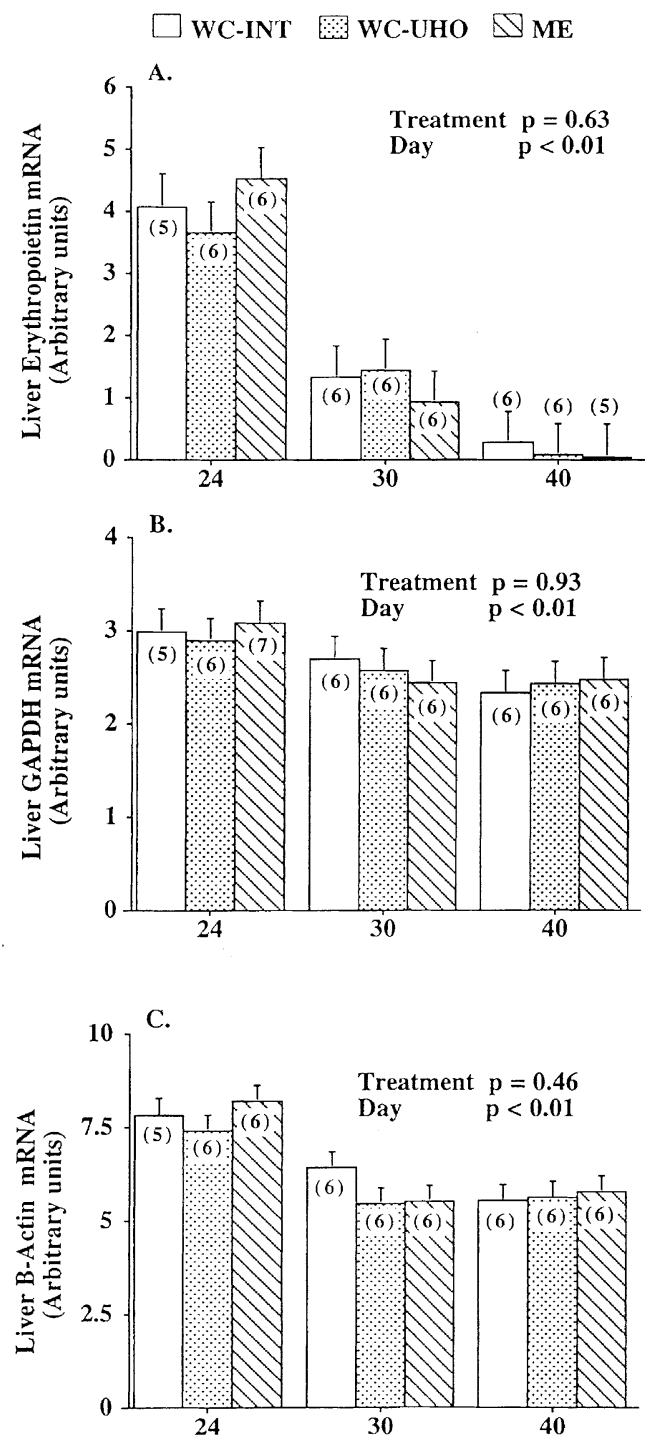

\section{Day of Gestation}

Fig. 2. (A) Results of densitometric analyses of steady-state levels of embryonic porcine liver erythropoietin mRNA. Results represent least squares means + S.E.M. Each experimental sample was adjusted by analysis of covariance using the absorbancy of the $\beta$-actin for the same sample as a covariate. Densitometric analyses of (B) glyceraldehyde phosphate dehydrogenase (GAPDH) and (C) $\beta$-actin are presented without adjustments. Numbers in parentheses represent the number of fetuses (one fetus/gilt) incorporated into each least-squares mean and S.E.M. One lane for a day-40 ME fetus was not readable by densitometric procedures and was not used, therefore, in 2A, $n=5$ for day-40 ME. Measures for GAPDH were conducted on one additional ME fetus on day 24 and hence $n=7$ in 2B. Statistics were performed on log-transformed data for erythropoietin mRNA. There were no treatment $\times$ day interactions $(P>0.47)$. 


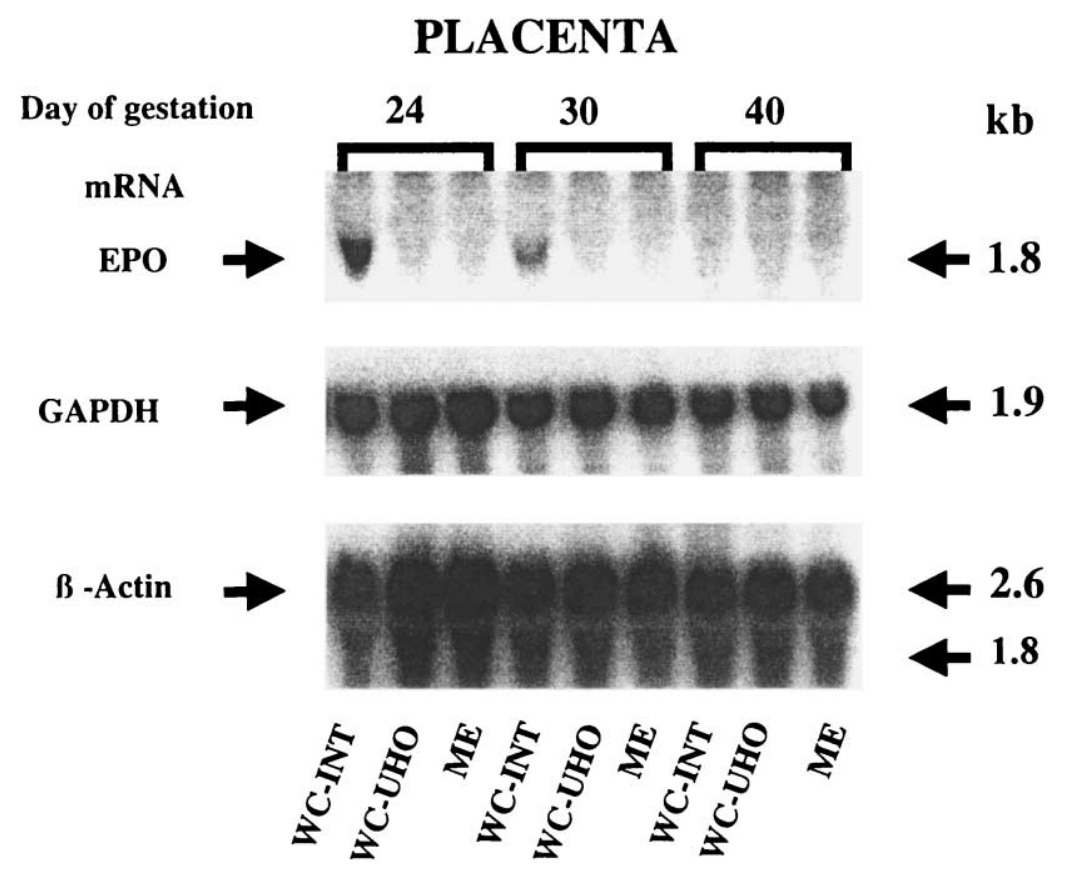

Fig. 3. Representative Northern analysis of EPO, glyceraldehyde-3-phosphate dehydrogenase (GAPDH), and $\beta$-actin mRNA from embryonic pig placental tissue at various gestational ages. All lanes consisted of $30 \mu \mathrm{g}$ total RNA. WC-INT: intact white crossbred gilts; WC-UHO: unilaterally-hysterectomized-ovariectomized white crossbred gilts; ME: intact Meishan gilts.

GAPDH, very similar data and identical interpretations are obtained (data not shown). In placental tissue, EPO mRNA was present in a few day 24 and day 30 placentae (Fig. 3) in an apparently random manner $(1 \times$ day $24 \mathrm{INT}, 1 \times$ day $30 \mathrm{INT}, 1 \times$ day $30 \mathrm{ME}$, and $1 \times$ day $30 \mathrm{UHO}$ ).

Both $\beta$-actin and GAPDH were highly expressed in embryonic liver and placental tissue (Figs. 1-3). For $\beta$-actin two transcripts were present: a major transcript at approximately $2600 \mathrm{bp}$, and a minor transcript at $1800 \mathrm{bp}$. The major transcript was used for calculations and statistical evaluations. Both mRNA decreased modestly but significantly $(P<0.01)$ in liver after day 24 in all treatments ( $\beta$-actin $29 \%$ decrease; GAPDH $19.4 \%$ decrease). There were no treatment effects on amounts of liver $\beta$-actin or GAPDH mRNA expression.

\subsection{Experiment II}

In Experiment I, it appeared that considerable embryonic death occurred between days 30 and 40 of gestation in UHO gilts (Pearson et al., 1998). Hence, a second study was conducted at day 35 when more embryos might be alive but undergoing developmental inadequacies that would cause their death within several days.

Embryonic weights did not differ between WC-INT and WC-UHO, but Meishan embryos were lighter than WC-INT, and for each pig model were less in the small versus large size 
Table 2

Measures in porcine embryos at day 35 of gestation

\begin{tabular}{|c|c|c|c|c|c|c|c|}
\hline Pig model & $\begin{array}{l}\text { Embryonic } \\
\text { size } \\
\text { (group) }\end{array}$ & $n^{\mathrm{a}}$ & $\begin{array}{l}\text { Embryonic } \\
\text { weight (g) }\end{array}$ & $\begin{array}{l}\text { Placental } \\
\text { weight (g) }\end{array}$ & $\begin{array}{l}\text { No. of } \\
\text { corpora } \\
\text { lutea }\end{array}$ & $\begin{array}{l}\text { No. of live } \\
\text { embryos }\end{array}$ & $\begin{array}{l}\text { Percent } \\
\text { survival }\end{array}$ \\
\hline \multirow[t]{3}{*}{ WC-INT } & Large & 14 & $4.1 \pm 0.2$ & $38.7 \pm 3.4$ & \multirow{3}{*}{$14.4 \pm 0.6$} & \multirow{3}{*}{$11.0 \pm 0.6$} & \multirow{3}{*}{$77.1 \pm 3.9$} \\
\hline & & & & & & & \\
\hline & Small & 14 & $3.4 \pm 0.2$ & $29.0 \pm 3.4$ & & & \\
\hline \multirow[t]{3}{*}{ WC-UHO } & Large & 9 & $3.9 \pm 0.2$ & $28.0 \pm 4.0$ & \multirow{3}{*}{$14.0 \pm 0.8$} & \multirow{3}{*}{$10.7 \pm 0.8$} & \multirow{3}{*}{$73.1 \pm 5.2$} \\
\hline & & & $21+02$ & & & & \\
\hline & & 8 & $0.1+0.2$ & $14.1 \pm 4.0$ & & & \\
\hline \multirow[t]{2}{*}{ ME } & Large & 13 & $3.4 \pm 0.2$ & $25.1 \pm 3.4$ & \multirow[b]{2}{*}{$14.7 \pm 0.6$} & \multirow[b]{2}{*}{$12.7 \pm 0.7$} & \multirow[b]{2}{*}{$86.6 \pm 4.3$} \\
\hline & Smoll & 12 & & $204+$ & & & \\
\hline \multicolumn{8}{|l|}{ ANOVA Evaluation } \\
\hline Pig model & & & $P=0.09$ & $P=0.02$ & 0.79 & 0.11 & $P=0.12$ \\
\hline Size & & & $P<0.001$ & $P<0.001$ & - & - & - \\
\hline Interaction & & & $P=0.08$ & $P=0.34$ & - & - & - \\
\hline \multicolumn{8}{|l|}{ A Priori Contrasts } \\
\hline WC-INT vs. ME & & & $P=0.03$ & $P=0.02$ & - & - & - \\
\hline WC-INT vs. WC-UHO & & & $P=0.48$ & $P=0.01$ & - & - & - \\
\hline WC vs. ME & & & - & - & - & $P=0.04$ & $P=0.04$ \\
\hline
\end{tabular}

${ }^{\text {a }}$ Here, $n$ represents the number of fetuses ( 1 large and 1 small per gilt) associated with each pig model, embryonic size group.

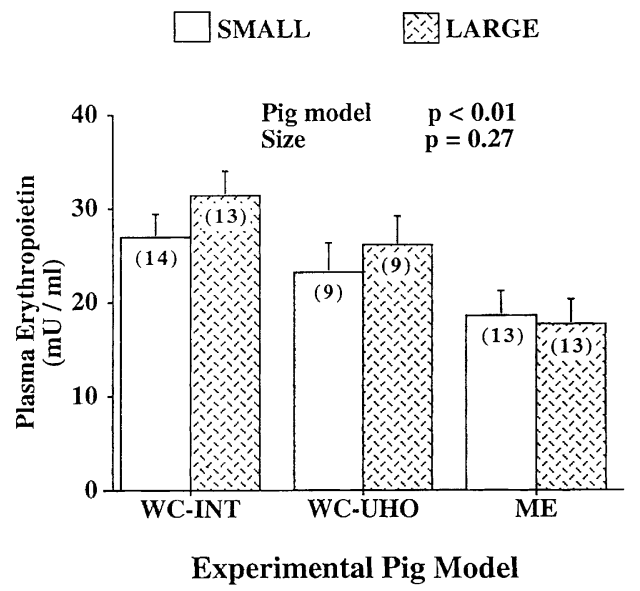

Fig. 4. Plasma erythropoietin concentrations in pig embryos at day 35 of gestation. Units are expressed relative to a human erythropoietin standard. Numbers in parentheses represent the number of embryos (one embryo/embryonic size/gilt) used in each least-squares mean and S.E.M. WC-INT: intact white crossbred gilts; WC-UHO: unilaterally-hysterectomized-ovariectomized white crossbred gilts; ME: intact Meishan gilts. There was no interaction between pig model and size $(P>0.49)$. 
A DAY 35 OF GESTATION
LIVER

mRNA
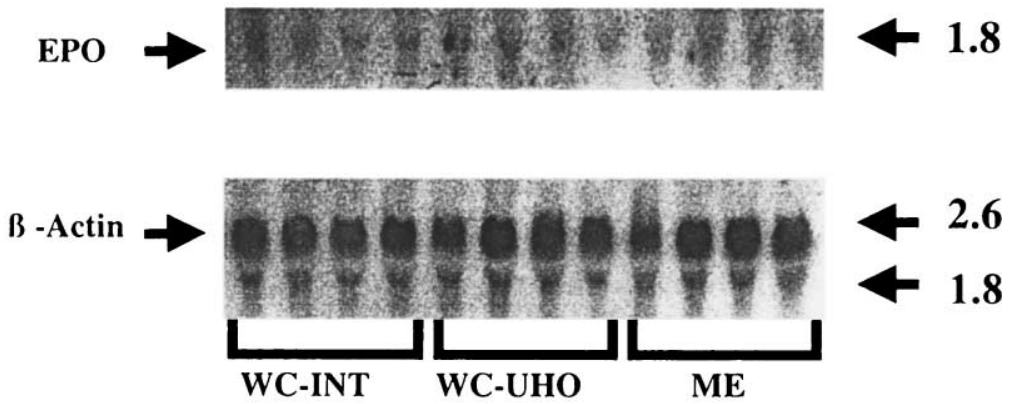

B SMALL $\square$ LARGE

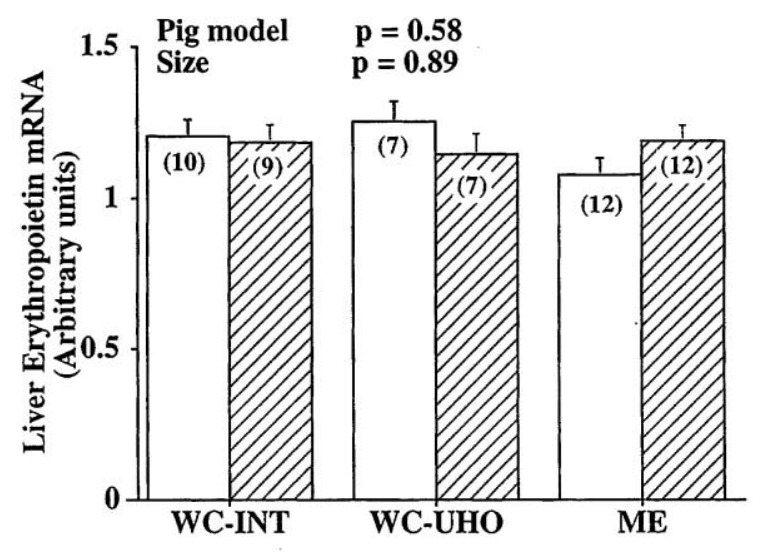

Experimental Pig Model

Fig. 5. (A) Representative Northern analysis of EPO and $\beta$-actin mRNA from embryonic pig liver at day 35 of gestation. All lanes consisted of $30 \mu \mathrm{g}$ total RNA. (B) Results of densitometric analyses of steady-state levels of embryonic liver erythropoietin mRNA at day 35 of gestation. Results represent least squares mean + S.E.M. Each erythropoietin measure was adjusted by analysis of covariance using the absorbancy of the $\beta$-actin for the same sample as a covariate. Numbers in parentheses represent the number of embryos (one embryo/embryonic size/gilt) used in each least-squares mean and S.E.M. There was no interaction between pig model and size $(P=0.47)$. WC-INT: intact white crossbred gilts; WC-UHO: unilaterally-hysterectomized-ovariectomized white crossbred gilts; ME: intact Meishan gilts. 
groups (Table 2). Placental weights were smaller not only in smaller fetuses within each animal model but also in Meishan versus WC-INT and in WC-UHO versus WC-INT (Table 2). The number of ovulations as measured by the number of viable corpora lutea at slaughter did not differ among pig models (Table 2). The number of live embryos was greater in ME gilts when compared with WC gilts using a priori contrasts (Table 2). Embryonic survival in ME gilts was greater than in WC gilts (Table 2). Plasma erythropoietin concentrations did not differ between embryonic size groups $(P=0.27)$ but were $33 \%$ lower $(P=0.002)$ in ME versus WC embryos (Fig. 4). Liver EPO mRNA expression were low but present on day 35 (Fig. 5a) and did not differ among animal models or embryonic weight groups (Fig. 5b). Liver EPO mRNA expression was not associated with plasma EPO concentrations $(P=0.31)$ nor with fetal $(P=0.46)$, placental $(P=0.84)$, or liver $(P=0.18)$ weights. Plasma EPO concentrations were similarly not associated with fetal $(P=0.78)$, placental $(P=0.28)$, or liver weights $(P=0.69)$. EPO mRNA expression could not be detected at this gestational age in placental tissue using Northern hybridization techniques. In kidney RNA preparations, EPO mRNA was barely discernable but not quantifiable in a few embryos (data not shown).

\section{Discussion}

In pigs, these results are the first to indicate a liver source of fetal erythropoietin during early gestation although the data do not rule out additional sources. As has been established in other species (Galson et al., 1994; Lim et al., 1994; Eckardt, 1995; Wintour et al., 1996), the porcine fetal liver expresses EPO mRNA at an early prenatal developmental stage. The approximately $1800 \mathrm{bp}$ size of the porcine mRNA corresponds reasonably well to the EPO mRNA for rat (1395 bp; Nagao et al., 1992), human fetal (1342 bp; Jacobs et al., 1985), monkey (1462 bp; Lin et al., 1986), and bovine species (1258 bp; Suliman et al., 1996). Decreasing levels of steady-state EPO mRNA expression between days 24 and 40 closely parallel the decrease in plasma EPO concentrations that we previously reported (Pearson et al., 1998). Observed decreases in liver EPO mRNA were somewhat modified by using amounts of $\beta$-actin and GAPDH mRNA expression as covariates as these were modestly but significantly reduced with fetal age. Hence their use, although permitting adjustment for lane-loading differences, produced more conservative evaluations of EPO mRNA age-related differences.

The cause of this age-related decrease in liver EPO mRNA is not known but four possibilities exist. One possibility is the changing profile of embryonic hemoglobins known to occur in porcine embryos at about this time (Weber et al., 1987). The percentages of these four hemoglobins, Gower I, Gower II, Heide I, and Heide II, decreases dramatically from approximately 25 to 35 days of gestation concomitant with a dramatic increase in adult hemoglobin A (Weber et al., 1987). As embryonic hemoglobins are produced in nucleated red blood cells (Kitchen and Brett, 1974), this decrease coincides with the maturation of the blood profile of erythrocytes and their precursors (Pearson et al., 1998). The Gower I and Heide I forms predominate in earlier embryos and have a greater oxygen affinity, thereby increasing the efficacy of transfer of oxygen from the maternal to embryonic circulation (Weber et al., 1987) while also providing less oxygen to tissues at a given partial pressure 
of oxygen (Jelkmann, 1992). In rats, this phenomenon led to increases in plasma erythropoietin (Lechermann and Jelkmann, 1985). Hence, higher liver EPO mRNA in day-24 embryos may reflect the presence of embryonic hemoglobins. A second possibility is that dramatic increases in total numbers of red blood cells (mature and immature) at this time (Pearson et al., 1998) provides more oxygen to tissues with a subsequent decrease in EPO production.

Thirdly, synthesis of EPO may shift from the liver to another tissue at a much earlier age in pigs than in other species. However, we could not detect any significant expression of kidney (the most logical next site of EPO synthesis) EPO mRNA using Northern analyses. In mice at about 19 days of gestation (term $=20$ days), the kidney appears to assume the major role of EPO production (Koury et al., 1988) whereas in rats the liver is the predominant source of EPO until 28 days of neonatal life (Eckardt et al., 1992). In fetal sheep, the fetal kidney appears to be involved in EPO synthesis as early as day 41 (0.28 gestational length; Wintour et al., 1996). Fetal sheep liver EPO mRNA expression declines after day 60 of gestation (term $=145$ days) whereas kidney EPO mRNA expression remains constant between days 60 and 100 and then declines to lesser amounts at 140 days (Lim et al., 1994).

Finally, age-related decreases in liver EPO mRNA expression may reflect the fact that at day 24 , expression is constitutive and by day 30 , expression is at least in part regulated by blood oxygen content. Such a phenomenon was apparent in fetal rats wherein at days 15 and 16 of gestation liver EPO was uninfluenced by hypoxia but after day 17 underwent an age-related decline in controls and increased in oxygen-deprived rats (Clemons et al., 1986). Once oxygen-associated control of EPO mRNA expression is established, expression under normoxic conditions is quite low to unmeasurable (Koury et al., 1989; Eckardt et al., 1992; Fu et al., 1993).

The current results also suggest the presence of placental EPO mRNA. This expression was very limited on day 24 and 30 and by days 35 and 40 could not be detected. Conrad et al. (1996) demonstrated immunoreactive EPO in the cytotrophoblasts and syncytiotrophoblasts of first- and second-trimester human placentae and in syncytiotrophoblasts of third-trimester placentae. However, RT-PCR was needed to detect placental EPO mRNA. Current results suggest the possibility that the porcine placenta during early pregnancy is an additional site of EPO production.

Oxygen is required by all living cells and is transported in the blood bound to hemoglobin found in erythrocytes and their precursors. In order to ensure cells have an adequate supply of oxygen, erythropoiesis is tightly coupled via EPO to oxygen tension (Huang and Bunn, 1995). EPO is a crucial growth factor required for normal erythropoiesis; in mice, homozygous for null mutations of EPO, erythropoiesis is greatly reduced and these embryos die about day 13 of gestation (Wu et al., 1995; Lin et al., 1996). Hence, if abnormal EPO mRNA expression were occurring, one would expect low EPO mRNA concomitant with low circulating EPO and reduced hemoglobin and hematocrit. Such associations, if prolonged and of sufficient magnitude, would ultimately lead to low oxygen availability and eventually cellular and embryonic death. Such associations were not apparent in our studies. If on the contrary, hypoxia were occurring due to other mechanisms such as reduced utero-placental blood flow or placental inadequacies (Maier et al., 1994) in the presence of a functional EPO sensing and production system, one might expect - 
depending on the rapidity and severity of the hypoxia - to measure increased EPO mRNA (Fu et al., 1993; Darby et al., 1995; Lim et al., 1996), plasma EPO (Kitanaka et al., 1989; Fu et al., 1993; Maier et al., 1993, 1994), and concomitantly increased hemoglobin and hematocrit (Kitanaka et al., 1989; Fu et al., 1993). In some experimental paradigms due to a time-lag in the stimulus-response coupling, there are significant negative associations between plasma EPO or EPO mRNA expression and red blood cell mass (Walle et al., 1987; Koury et al., 1989) or hemoglobin (Kling et al., 1996). These relationships were not observed. Our data suggest, therefore, that in the embryos measured, EPO production (as reflected by tissue mRNA and plasma concentrations) was not compromised and levels present represent normal variability among animals. These data also suggest that either oxygen availability was not compromised in these embryos, or that the oxygen sensing system and/or its coupling to EPO production was not yet functional. Strong relationships among EPO mRNA, plasma EPO, hematocrit and hemoglobin have been previously reported when animals have been made hypoxic and EPO production is stimulated (Kitanaka et al., 1989; Koury et al., 1989; Tan et al., 1992; Fu et al., 1993; Darby et al., 1995).

A factor that potentially influences our results and their interpretation is the limited number of fetuses sampled per gilt in our first study. An increased number of fetuses per gilt might have allowed detection of differences among animal models and perhaps improved the accuracy of results. In the second study, we attempted to address this issue by increasing the number of gilts in each treatment and by sampling two fetuses per gilt. It is also worthy of mention that in our second study at day 35, there were no differences in fetal survival between UHO and INT gilts as occurred at day 40 in the first experiment. This suggests that losses in the first study occurred after day 35 .

Previous studies have indicated associations among intrauterine growth retardation, hypoxia, and EPO. In hypoxemic sheep, growth retardation of fetuses was observed (Jacobs et al., 1986). Umbilical blood EPO concentrations in some human newborns indicated prolonged fetal hypoxia and were significantly correlated with fetal growth retardation (Maier et al., 1993). Small-for-gestational-age human fetuses (18-36 weeks of gestation) were hypoxemic (Nicolaides et al., 1989), and small-for-gestational-age human fetuses (24-36 weeks of gestation) had greater umbilical blood EPO concentrations than adequate-for-gestational-age fetuses (Lemery et al., 1994). Hence, in the current study, it was hypothesized that smaller embryos within a pig model might be challenged in terms of oxygen availability and potential survival and that altered EPO might be associated with this condition. However, there were no measurable associations between fetal or placental size and tissue EPO mRNA or plasma EPO concentrations. Again, an adequate oxygen supply was suggested in all living embryos irrespective of size.

In summary, porcine embryonic liver provides one source of plasma EPO as evidenced by the presence of EPO mRNA in this tissue. Porcine placenta may also represent a source of EPO on days 24-30. Kidney EPO mRNA was measured only on day 35 and was essentially absent. Hence, it is not known when measurable EPO mRNA expression appears in this tissue. In the live embryos measured, EPO mRNA expression and plasma concentrations were not associated with embryonic size, and there was no obvious positive association with survival. Such data suggest normal EPO transcription or translation and an absence of hypoxia in living embryos during this gestational period. 


\section{Acknowledgements}

The authors want to express their appreciation to Terri Alberts, Frank Reno, Dave Sypherd, and Jenell Woods for technical assistance and to Linda Parnell for secretarial assistance with the manuscript.

\section{References}

Bazer, F.W., Thatcher, W.W., Martinat-Botte, F., Terqui, M., 1988. Conceptus development in Large White and prolific Chinese Meishan pigs. J. Reprod. Fertil. 84, 37-42.

Bunn, H.F., Gu, J., Huang, L.E., Park, J.W., Zhu, H., 1998. Erythropoietin: a model system for studying oxygen-dependent gene regulation. J. Exp. Biol. 201, 1197-1201.

Christenson, R.K., Leymaster, K.A., Young, L.D., 1987. Justification of unilateral hysterectomy-ovariectomy as a model to evaluate uterine capacity in swine. J. Anim. Sci. 65, 738-744.

Christenson, R.K., Vallet, J.L., Leymaster, K.A., Young, L.D., 1993. Uterine function in Meishan pigs. J. Reprod. Fertil. Suppl. 48, 279-289.

Clemons, G.K., Fitzsimmons, S.L., DeManincor, D., 1986. Immunoreactive erythropoietin concentrations in fetal and neonatal rats and the effects of hypoxia. Blood 68, 892-899.

Conrad, K.P., Benyo, D.F., Westerhausen-Larsen, A., Miles, T.M., 1996. Expression of erythropoietin by the human placenta. FASEB J. 10, 760-766.

Darby, I.A., Evans, B.A., Fu, P., Lim, G.B., Moritz, K.M., Wintour, E.M., 1995. Erythropoietin gene expression in fetal and adult sheep kidney. Br. J. Haematol. 89, 266-270.

Eckardt, K.U., 1995. The ontogeny of the biological role and production of erythropoietin. J. Perinat. Med. 23, 19-29.

Eckardt, K.U., Ratcliffe, P.J., Tan, C.C., Bauer, C., Kurtz, A., 1992. Age-dependent expression of the erythropoietin gene in rat liver and kidneys. J. Clin. Invest. 89, 753-760.

Fisher, J.W., 1997. Erythropoietin: physiologic and pharmacologic aspects. Proc. Soc. Exp. Biol. Med. 216, 358369.

Fu, P., Evans, B., Lim, G.B., Moritz, K., Wintour, E.M., 1993. The sheep erythropoietin gene: molecular cloning and effect of hemorrhage on plasma erythropoietin and renal/liver messenger RNA in adult sheep. Mol. Cell. Endocrinol. 93, 107-116.

Galson, D.L., Blanchard, K.L., Fandrey, J., Goldberg, M.A., Bunn, H.F., 1994. Cis elements that regulate the erythropoietin gene. Ann. NY Acad. Sci. 718, 21-30.

Goldberg, M.A., Dunning, S.P., Bunn, H.F., 1988. Regulation of the erythropoietin gene: evidence that the oxygen sensor is a heme protein. Science 242, 1412-1415.

Huang, L.E., Bunn, H.F., 1995. Regulation of erythropoietin gene expression. Curr. Opin. Hematol. 2, 125131.

Jacobs, K., Shoemaker, C., Rudersdorf, R., Neill, S.D., Kaufman, R.J., Mufson, A., Seehra, J., Jones, S.S., Hewick, R., Fritsch, E.F., 1985. Isolation and characterization of genomic and cDNA clones of human erythropoietin. Nature 313, 806-810.

Jacobs, R., Falconer, J., Robinson, J.S., Webster, M.E., 1986. Effect of hypoxia on the initiation of secondary wool follicles in the fetus. Aust. J. Biol. Sci. 39, 79-83.

Jelkmann, W., 1992. Erythropoietin: structure, control of production, and function. Physiol. Rev. 72, 449-489.

Kitanaka, T., Alonso, J.G., Gilbert, R.D., Siu, B.L., Clemons, G.K., Longo, L.D., 1989. Fetal responses to long-term hypoxemia in sheep. Am. J. Physiol. 256, R1348-R1354.

Kitchen, H., Brett, I., 1974. Embryonic and fetal hemoglobin in animals. Ann. NY Acad. Sci. 241, 653-671.

Kling, P.J., Schmidt, R.L., Roberts, R.A., Widness, J.A., 1996. Serum erythropoietin levels during infancy: associations with erythropoiesis. J. Pediatr. 128, 791-796.

Knight, J.W., Bazer, F.W., Thatcher, W.W., Franke, D.E., Wallace, H.D., 1977. Conceptus development in intact and unilaterally hysterectomized-ovariectomized gilts: interrelations among hormonal status, placental development fetal fluids and fetal growth. J. Anim. Sci. 44, 620-637. 
Koury, M.J., Bondurant, M.C., Graber, S.E., Sawyer, S.T., 1988. Erythropoietin messenger RNA levels in developing mice and transfer of ${ }^{125}$ I-erythropoietin by the placenta. J. Clin. Invest. 82, 154-159.

Koury, S.T., Koury, M.J., Bondurant, M.C., Caro, J., Graber, S.E., 1989. Quantitation of erythropoietin-producing cells in kidneys of mice by in situ hybridization: correlation with hematocrit, renal erythropoietin mRNA, and serum erythropoietin concentration. Blood 74, 645-651.

Lechermann, B., Jelkmann, W., 1985. Erythropoietin production in normoxic and hypoxic rats with increased blood $\mathrm{O}_{2}$ affinity. Respir. Physiol. 60, 1-8.

Lemery, D.J., Santolaya, J., Serre, A.F., Denoix, S., Besse, G.H., Vanlieferinghen, P.C., Bezou, M.J., Gaillard, G., Jacquetin, B., 1994. Serum erythropoietin in small for gestational age fetuses. Biol. Neonate 65, 8993.

Lim, G.B., Jeyaseelan, K., Wintour, E.M., 1994. Ontogeny of erythropoietin gene expression in the sheep fetus: effect of dexamethasone at 60 days of gestation. Blood 84, 460-466.

Lim, G.B., Moritz, K., Jeyaseelan, K., Wintour, E.M., 1996. Effect of hemorrhage and nephrectomy on erythropoietin gene expression in the ovine fetus. Mol. Cell. Endocrinol. 117, 101-109.

Lin, C.-S., Lim, S.-K., D’Agati, V., Costantini, F., 1996. Differential effects of an erythropoietin receptor gene disruption on primitive and definitive erythropoiesis. Genes Dev. 10, 154-164.

Lin, F.K., Lin, C.H., Lai, P.H., Browne, J.K., Egrie, J.C., Smalling, R., Fox, G.M., Chen, K.K., Castro, M., Suggs, S., 1986. Monkey erythropoietin gene: cloning, expression and comparison with the human erythropoietin gene. Gene 44, 201-209.

Maier, R.F., Böhme, K., Dudenhausen, J.W., Obladen, M., 1993. Cord blood erythropoietin in relation to different markers of fetal hypoxia. Obstet. Gynecol. 81, 575-580.

Maier, R.F., Günther, A., Vogel, M., Dudenhausen, J.W., Obladen, M., 1994. Umbilical venous erythropoietin and umbilical arterial $\mathrm{pH}$ in relation to morphologic placental abnormalities. Obstet. Gynecol. 84, 81-87.

Maxwell, A.P., Lappin, T.R., Johnston, C.F., Bridges, J.M., McGeown, M.G., 1990. Erythropoietin production in kidney tubular cells. Br. J. Haematol. 74, 535-539.

Nagao, M., Suga, H., Okano, M., Masuda, S., Narita, H., Ikura, K., Sasaki, R., 1992. Nucleotide sequence of rat erythropoietin. Biochim. Biophys. Acta 1171, 99-102.

Nicolaides, K.H., Economides, D.L., Soothill, P.W., 1989. Blood gases, pH, and lactate in appropriate- and small-for-gestational-age fetuses. Am. J. Obstet. Gynecol. 161, 996-1001.

Pearson, P.L., Klemcke, H.G., Christenson, R.K., Vallet, J.L., 1998. Uterine environment and breed effects on erythropoiesis and liver protein secretion in late embryonic and early fetal swine. Biol. Reprod. 58, 911918.

Pope, W.F., 1994. Embryonic mortality in swine. In: Zavy, M.T., Geisert, R.D. (Eds.), Embryonic Mortality in Domestic Species. CRC Press, Boca Raton, FL, pp. 53-77.

Rich, I.N., Riedel, W., Brackmann, I., Schnappauf, U., Zimmermann, F., Vogt, C., Noé, G., 1994. The initiation of the hemopoietic system. The response of embryonic cells to growth factors and expression of erythropoietin and erythroid-relevant genes during murine development. Ann. NY Acad. Sci. 718, 147-162.

SAS, 1997. SAS System for Elementary Statistical Analysis, 2nd Edition. SAS Institute, Inc., Cary, NC.

Srinivas, V., Zhu, X., Salceda, S., Nakamura, R., Caro, J., 1998. Hypoxia-inducible factor 1a (HIF-1a) is a non-heme iron protein. Implications for oxygen sensing. J. Biol. Chem. 273, 18019-18022.

Suliman, H.B., Majiwa, P.A., Feldman, B.F., Mertens, B., Logan-Henfrey, L., 1996. Cloning of a cDNA encoding bovine erythropoietin and analysis of its transcription in selected tissues. Gene 171, 275-280.

Tan, C.C., Eckardt, K.U., Firth, J.D., Ratcliffe, P.J., 1992. Feedback modulation of renal and hepatic erythropoietin mRNA in response to graded anemia and hypoxia. Am. J. Physiol. 263, F474-F481.

Vallet, J.L., Smith, T.P.L., Sonstegard, T., Pearson, P.L., Christenson, R.K., Klemcke, H.G., 1999. Isolation of complementary deoxyribonucleic acids encoding putative secreted and membrane-bound folate binding proteins from endometrium of swine. Biol. Reprod. 61, 372-379.

Walle, A.J., Wong, G.Y., Clemons, G.K., Garcia, J.F., Niedermayer, W., 1987. Erythropoietin-hematocrit feedback circuit in the anemia of end-stage renal disease. Kidney Intern. 31, 1205-1209.

Webel, S.K., Dziuk, P.J., 1974. Effect of stage of gestation and uterine space on prenatal survival in the pig. J. Anim. Sci. 38, 960-963.

Weber, R.E., Kleinschmidt, T., Braunitzer, G., 1987. Embryonic pig hemoglobins Gower I $\left(\zeta_{2} \varepsilon_{2}\right)$, Gower II $\left(\alpha_{2} \varepsilon_{2}\right)$, Heide I $\left(\zeta_{2} \vartheta_{2}\right)$ and Heide II $\left(\alpha_{2} \vartheta_{2}\right)$ : oxygen-binding functions related to structure and embryonic oxygen supply. Respir. Physiol. 69, 347-357. 
Wen, D., Boissel, J.-P.R., Tracy, T.E., Gruninger, R.H., Mulcahy, L.S., Czelusniak, J., Goodman, M., Bunn, H.F., 1993. Erythropoietin structure-function relationships: high degree of sequence homology among mammals. Blood 82, 1507-1516.

Wintour, E.M., Butkus, A., Earnest, L., Pompolo, S., 1996. The erythropoietin gene is expressed strongly in the mammalian mesonephric kidney. Blood 88, 3349-3353.

Wu, H., Liu, X., Jaenisch, R., Lodish, H.F., 1995. Generation of committed erythroid BFU-E and CFU-E progenitors does not require erythropoietin or the erythropoietin receptor. Cell 83, 59-67. 